\title{
Can Preoperative Haematological Parameters Predict Pathology Results in Patients Undergoing Open Prostatectomy Due to Benign Prostatic Hyperplasia? A Retrospective Study
}

\author{
Benign Prostat Hiperplazisi Nedeniyle Açık Prostatektomi \\ Uygulanan Hastalarda Preoperatif Hematolojik Parametreler \\ Patoloji Sonuçlarını Öngörebilir mi? Retrospektif Bir Çalışma
}

(D) Ahmet Güzel

Aydın State Hospital, Clinic of Urology, Aydın, Turkey

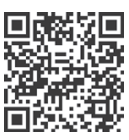

Keywords

Prostate cancer, open prostatectomy, benign prostatic hyperplasia, lymphocytes, neutrophils

\section{Anahtar Kelimeler}

Prostat kanseri, açık prostatektomi, benign prostat hiperplazisi, lenfositler, nötrofiller

Received/Geliş Tarihi : 23.12 .2020

Accepted/Kabul Tarihi : 18.01.2021

doi:10.4274/meandros.galenos.2021.32659

Address for Correspondence/Yazışma Adresi: Ahmet Güzel MD,

Aydın State Hospital, Clinic of Urology, Aydın, Turkey

Phone : +90 5053039414

E-mail :drahmetguzel@yahoo.com

ORCID ID: orcid.org/0000-0002-1101-1149

(C) Meandros Medical and Dental Journal, Published by Galenos Publishing House.

This is article distributed under the terms of the Creative Commons Attribution NonCommercial 4.0 International Licence (CC BY-NC 4.0).

\section{Abstract}

Objective: Although the incidence of incidental prostate cancer (IPCa) has decreased in patients undergoing open prostatectomy with the increasing use of prostate-specific antigen (PSA), cases of IPCa are still reported. This study aimed to investigate the rate of IPCa in our patients who underwent open prostatectomy and to find the relationship between haematological parameters and pathology results.

Materials and Methods: Data of patients who underwent open prostatectomy in our urology clinic between January 2014 and December 2019 were retrospectively investigated. Patient age, preoperative PSA level, prostate volume, post-void residual urine volume, history of urethral catheterisation, presence of accompanying bladder stones, pathology results of prostate biopsy, post-operative pathology results, haematological parameters, neutrophil-to-lymphocyte ratio (NLR) and platelet-to-lymphocyte ratio (PLR) were evaluated.

Results: A total of 83 male patients were included in the study. The mean patient age was $68.89 \pm 6.72$ years. The mean preoperative PSA value was $7.46 \pm 6.23 \mathrm{ng} / \mathrm{mL}$. Benign prostatic hyperplasia was detected in the post-operative pathology results of all patients; however, prostate adenocarcinoma was found in six (7.2\%) and chronic prostatitis accompanied with benign prostatic hyperplasia was detected in 46 (55.4\%) patients. PLR and NLR were higher in patients with IPCa than in patients without IPCa. The difference was statistically significant in terms of PLR $(p=0.010)$. By contrast, the mean lymphocyte count was significantly lower in patients with IPCa than in those without IPCa $(p=0.009)$.

Conclusion: This study showed that the rate of IPCa in our clinic was similar to that in literature. Results suggest that evaluation of preoperative haematological parameters in patients who underwent open prostatectomy may guide urologists and pathologists in predicting pathological conditions. 
Öz

Amaç: Prostat spesifik antijen (PSA) kullanım sıklığının artması ile açık prostatektomi uygulanan hastalarda insidental prostat kanseri (IPK) görülme sıkığı azalmış olsa da devam etmektedir. Bu çalışmanın amacı, açık prostatektomi uygulanan hastalarımızda IPK oranı ve hematolojik parametreler ile patoloji sonuçları arasında bir ilişki olup olmadığını araştırmaktır.

Gereç ve Yöntemler: Ocak 2014 - Aralık 2019 tarihleri arasında üroloji kliniğimizde açık prostatektomi geçiren hastaların verileri geriye dönük olarak incelendi. Hastaların yaşı, ameliyat öncesi PSA değeri, prostat hacmi, işeme sonrası rezidüel idrar miktarı, üretral kateterizasyon öyküsü, eşlik eden mesane taşı varlığı, prostat biyopsisinin patoloji sonuçları, post-operatif patoloji sonuçları, hematolojik parametreler ve nötrofil-lenfosit oranı (NLO) ve trombosit-lenfosit oranı (PLO) değerlendirildi.

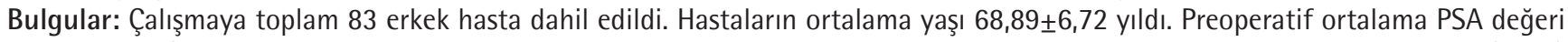
$7,46 \pm 6,23 \mathrm{ng} / \mathrm{mL}$ idi. Tüm hastaların post-operatif patoloji sonuçlarında benign prostat hiperplazisi saptanırken, 6 hastada $(\% 7,2)$ prostat adenokarsinomu ve 46 hastada $(\% 55,4)$ kronik prostatitin benign prostat hiperplazisine eşlik ettiği görüldü. IPK'li hastalarda, IPK olmayan hastalara göre PLO ve NLO'nun daha yüksek olduğu görüldü. Bu yükseklik PLO açısından istatistiksel olarak anlamlıydı $(p=0.010)$. Öte yandan, ortalama lenfosit sayısı IPK olan hastalarda IPK olmayan hastalara göre anlamlı olarak daha düşüktü ( $p=0,009)$. Sonuç: Bu çalışma, kliniğimizde IPK oranının literatürdekine benzer olduğunu göstermiştir. Ayrıca sonuçlar, açık prostatektomi uygulanan hastalarda preoperatif hematolojik parametrelerin değerlendirilmesinin ürologlar ve patologlar için patoloji sonuçlarını tahmin etmede yol gösterici olabileceğini düşündürmektedir.

\section{Introduction}

Benign enlargement of the prostate as a result of the proliferation of smooth muscle and epithelial cells in the area of the prostate closest to the urethra, called as the transitional zone, is benign prostatic hyperplasia (BPH). The enlargement of the prostate and cell proliferation cause lower urinary tract symptoms (LUTS) by narrowing the urethral lumen. $\mathrm{BPH}$ is the most common benign neoplasm in aging men. While it occurs about $8 \%$ of men in their 40 s, this rate rises to $90 \%$ for men over 90 years old (1).

In addition to medical treatment options, there are surgical treatment options in the treatment of patients with LUTS due to BPH (2). Advances in the surgical techniques over the years have given rise to the widespread use of minimally invasive techniques in surgical treatment of BPH (2). However, open prostatectomy is still an alternative surgical treatment to minimally invasive treatments with a strong degree of recommendation in the guidelines for men with absolute or relative surgical indications and prostate volume $>80 \mathrm{~mL}(2,3)$. Open prostatectomy is still the gold standard surgical treatment in large prostates in many clinics where endoscopic enucleation techniques cannot be applied.

The rate of incidental prostate cancer (IPCa) decreased with increasing frequency of the use of prostate-specific antigen (PSA). However, it has been reported in various studies that the rates of IPCa varied between $1.4-16.7 \%$, according to the pathology samples of the patients undergoing prostate surgery $(4,5)$.
In addition to their use as indicators of systemic inflammatory response in many studies $(6,7)$, it was investigated whether neutrophil-to-lymphocyte ratio (NLR) and platelet-to-lymphocyte ratio (PLR) were effective in predicting oncological outcomes in malignancies (8).

In this study, it was aimed to identify the rate of IPCa in our clinic and to determine whether NLR and PLR, which are hematological parameters, are predictive factors in predicting pathology results by examining the pathology results of patients who underwent open prostatectomy in our clinic.

\section{Materials and Methods}

Following the approval of the Aydın Adnan Menderes University Non-Interventional Clinical Research Ethics Committee (decision no: 11, date: 06.08.2020), the data of patients who underwent open prostatectomy due to BPH between January 2014 and December 2019 in our hospital were retrospectively analyzed. The study protocol was designed in compliance with the Declaration of Helsinki. Informed consent was obtained from patients.

All patients who underwent open prostatectomy in our clinic were included in our study, regardless of whether they had preoperatively undergone transrectal ultrasound-guided biopsy (TRUS-Bx) (whose pathology was not prostate adenocarcinoma) or not.

Patients' age, preoperative PSA value, estimated prostate volume (EPV), post-void residual urine (PVR), history of urethral catheterization, presence 
of accompanying bladder stones, prostate biopsy pathology results if performed, and post-operative pathology results were evaluated. In addition, leukocyte, lymphocyte, neutrophil and platelet counts obtained from preoperative routine hematological laboratory results, and the NLR and PLR calculated from these data were assessed.

Serum PSA was collected from final laboratory results just before biopsy procedures were performed in those undergoing prostate biopsies. Serum PSA was collected from the last laboratory results just before open prostatectomy was performed in patients without prostate biopsy. We collected EPVs, PVRs and presence of accompanying bladder stones from their initial trans-abdominal ultrasound reports. The NLR and PLR were obtained by dividing the absolute neutrophil count or platelet count directly towards their absolute lymphocyte count. Patients whose data could not be reached or were incomplete were excluded from the study.

\section{Statistical Analysis}

IBM SPSS Statistics for Windows version 25 (IBM Corp., Armonk, NY) was used for data analysis. Kolmogorov-Smirnov test was used as the test of normal distribution. In the statistical analysis, student's t-test was used for normally distributed data and Mann-Whitney $U$ test for data not distributed normally. Chi-square test was used in the comparison of categorical data, and the level of significance was taken as 0.05 for all tests.

\section{Results}

A total of 83 male patients with an age ranging from 55 to 84 years were included. The mean age of the patients was $68.89 \pm 6.72$ years. The mean PSA level and the mean EPV were $7.46 \pm 6.23 \mathrm{ng} /$ $\mathrm{mL}$ and $107.3 \pm 38.7 \mathrm{~mL}$, respectively. The mean PVR was $208.67 \pm 172.43 \mathrm{~mL}$ and ranged between 30 to $840 \mathrm{~mL}$. (Table 1). It was observed that preoperative urethral catheterization was performed in $72.3 \%$ of patients $(n=60)$ and bladder stones were detected in 17 patients (20.5\%). Preoperative TRUS-Bx was performed in 27 patients (32.5\%). In the patients with TRUS-Bx, the mean PSA level was $14.02 \pm 6.50 \mathrm{ng} / \mathrm{mL}$ and the mean EPV was $114.59 \pm 39.68 \mathrm{~mL}$. The mean PSA level of the patients with TRUS-Bx was significantly higher compared to the patients without TRUS-BX $(4.30 \pm 2.57)(p<0.05)$. The mean age of the patients with TRUS-Bx was significantly lower compared to the patients without TRUS-Bx $(66.37 \pm 5.46$ years vs $70.11 \pm 6.97$ years, respectively) $(p<0.05)$. Based on the evaluation of patients' pathology results, in addition to the diagnosis of $\mathrm{BPH}$ in all patients, prostate cancer was detected in 6 patients $(7.2 \%)$ and chronic prostatitis in 46 patients (55.4\%). In three patients with IPCa, TRUS-Bx was not performed before the surgey since PSA levels were normal and there was no suspicious finding in the rectal examination. However, it was performed in the remaining three patients. It was seen that the mean PSA level and the mean EPV in the patients with IPCa were $9.85 \pm 6.39 \mathrm{ng} / \mathrm{mL}$ and $119.67 \pm 23.75 \mathrm{~mL}$, respectively. The lymphocyte counts of the patients without IPCa $(2.73 \pm 0.71)$ were higher than those with IPCa $(1.89 \pm 0.64)$, and this difference was statistically significant $(p=0.009)$. The mean PLR in the patients with IPCa (158.13 \pm 79.02$)$ was significantly higher than that in the patients without IPCa $(80.82 \pm 18.01)(p=0.010)$ (Table 1). IPCa was in Gleason score $3+3=6$ in all patients and no increase in PSA was detected in any of them, although they received no additional treatment. There was no significant difference in terms of PSA levels, EPV, PVR, leukocyte, neutrophil, platelet and lymphocyte counts, as well as NLR, PLR among patients with and without chronic prostatitis (Table 2).

\section{Discussion}

Open prostatectomy is a treatment procedure which has a strong recommendation by guidelines

\begin{tabular}{|l|l|}
\hline \multicolumn{2}{|l|}{ Table 1. Patient baseline characteristics } \\
\hline Characteristic & $\mathbf{n}=83$ \\
\hline Age (years) & $68.89 \pm 6.72(55-84)$ \\
\hline PSA (ng/dL) & $7.46 \pm 6.23$ \\
\hline EPV (mL) & $107.3 \pm 38.7(46-225)$ \\
\hline PVR (mL) & $208.67 \pm 172.43(30-840)$ \\
\hline Leucocyte count $\left(\times 10^{3} / \mathrm{mm}^{3}\right)$ & $8.41 \pm 2.49$ \\
\hline Neutrophil count $\left(\times 10^{3} / \mathrm{mm}^{3}\right)$ & $5.61 \pm 2.19$ \\
\hline Lymphocyte count $\left(\times 10^{3} / \mathrm{mm}^{3}\right)$ & $1.94 \pm 0.67$ \\
\hline Platelet count $\left(x 10^{3} / \mathrm{mm}^{3}\right)$ & $261.92 \pm 71.42$ \\
\hline NLR & $3.43 \pm 3.16$ \\
\hline PLR & $152.54 \pm 78.82$ \\
\hline $\begin{array}{l}\text { PSA: Prostate-spesific antigen, EPV: Estimated prostate volume, PVR: } \\
\text { Post-void residual urine, NLR: Neutrophil-to-lymphocyte ratio, PLR: } \\
\text { Platelet-to-lymphocyte ratio }\end{array}$ \\
\hline
\end{tabular}




\begin{tabular}{|c|c|c|c|c|c|c|}
\hline & \multicolumn{3}{|c|}{ Chronic prostatitis } & \multicolumn{3}{|c|}{ Incidental prostate cancer } \\
\hline & $\begin{array}{l}\text { Patients with CP } \\
(n=46)\end{array}$ & $\begin{array}{l}\text { Patients without } \\
\text { CP ( } n=37)\end{array}$ & $\mathbf{p}$ & $\begin{array}{l}\text { Patients with } \\
\text { IPCa (n=6) }\end{array}$ & $\begin{array}{l}\text { Patients without } \\
\text { IPCa }(n=77)\end{array}$ & p \\
\hline Age (years) & $68.72 \pm 7.47$ & $69.11 \pm 5.74$ & 0.794 & $67.50 \pm 4.037$ & $69.00 \pm 6.89$ & 0.601 \\
\hline PSA (ng/dL) & $7.89 \pm 5.59$ & $6.94 \pm 6.99$ & 0.134 & $9.85 \pm 6.39$ & $7.28 \pm 6.22$ & 0.235 \\
\hline $\mathrm{EPV}(\mathrm{mL})$ & $102.34 \pm 37.52$ & $113.51 \pm 39.75$ & 0.124 & $119.67 \pm 23.75$ & $106.36 \pm 39.56$ & 0.421 \\
\hline PVR (mL) & $233.08 \pm 207.23$ & $178.32 \pm 111.06$ & 0.433 & $181.17 \pm 117.25$ & $210.82 \pm 176.38$ & 0.937 \\
\hline Leucocyte count $\left(\times 10^{3} / \mathrm{mm}^{3}\right)$ & $8.57 \pm 2.70$ & $8.21 \pm 2.22$ & 0.611 & $8.33 \pm 2.52$ & $9.45 \pm 1.99$ & 0.120 \\
\hline Neutrophil count $\left(\times 10^{3} / \mathrm{mm}^{3}\right)$ & $5.87 \pm 2.54$ & $5.29 \pm 1.66$ & 0.336 & $5.59 \pm 2.25$ & $5.87 \pm 1.35$ & 0.351 \\
\hline Lymphocyte count $\left(\times 10^{3} / \mathrm{mm}^{3}\right)$ & $1.85 \pm 0.68$ & $2.07 \pm 0.66$ & 0.127 & $1.89 \pm 0.64$ & $2.73 \pm 0.71$ & $0.009 *$ \\
\hline Platelet count $\left(\times 10^{3} / \mathrm{mm}^{3}\right)$ & $268.85 \pm 73.09$ & $253.30 \pm 69.32$ & 0.327 & $265.43 \pm 71.26$ & $216.83 \pm 62.11$ & 0.109 \\
\hline NLR & $4.05 \pm 4.72$ & $2.68 \pm 0.83$ & 0.079 & $3.53 \pm 3.73$ & $2.23 \pm 0.62$ & 0.086 \\
\hline PLR & $167.56 \pm 91.41$ & $133.87 \pm 55.31$ & 0.056 & $158.13 \pm 79.02$ & $80.82 \pm 18.01$ & $0.010 *$ \\
\hline \multicolumn{7}{|c|}{$\begin{array}{l}\text { CP: Chronic prostatitis, IPCa: Incidental prostate cancer, PSA: Prostate-spesific antigen, EPV: Estimated prostate volume, PVR: Post-void residual urine, } \\
\text { NLR: Neutrophil-to-lymphocyte ratio, PLR: Platelet-to-lymphocyte ratio } \\
{ }^{*} \text { p }<0.05 \text { Intergroup significant difference, Mann-Whitney U test }\end{array}$} \\
\hline
\end{tabular}

for patients with bladder outlet obstruction with a prostate volume $>80 \mathrm{~mL}(2,3)$. However, as a result of advances in laser technology and minimally invasive surgical technique, holmium laser enucleation of the prostate (HoLEP) has taken its place in surgical treatment with similar success rates and a strong recommendation in the guidelines (2). While IPCa was detected in quite high rates in the past, the rate of prostate biopsy has been increased due to the widespread use of PSA and of different combinations of its forms. Therefore, the IPCa detection rate has decreased significantly recently $(4,5)$. Although the rate of IPCa is decreasing today, it is important to determine the predictive factors in terms of diagnosis and treatment planning. We evaluated some clinical and laboratory parameters in addition to PSA in order to detect IPCa in cases undergoing open prostatectomy and this study demonstrated that the lymphocyte counts and PLR were predictive factors in predicting pathology results.

In the study of Otsubo et al. (9) consisting of 365 patients undergoing HoLEP and in the study of Güner and Şeker (10) in 124 patients undergoing open prostatectomy, the rates of IPCa were $6.8 \%$ and $4 \%$, respectively. In addition, while there were significant differences in terms of the EPV and preoperative PSA levels between the patients with BPH and IPCa in the study of Otsubo et al. (9), no significant difference was observed in terms of these two parameters in the study of Güner and Şeker (10). In agreement with the study of Güner and Şeker (10), this study detected that there was no significant difference between the patients with BPH and IPCa in terms of the EPV and preoperative PSA levels. In addition, the present study showed that the rate of IPCa was $7.2 \%$ similar to the rates in those two previous studies.

It is known that the PSA level is not sufficient alone in detecting prostate cancer because it also increases in common diseases such as BPH and prostatitis (11). NLR and PLR, potential markers for determining inflammation, are used for differential diagnosis or prognostic predictors of various diseases such as cancer and inflammatory diseases in many studies $(12,13)$. Leukocytes, mainly lymphocytes, are one of the most significant markers in many cancers, apart from prostate cancer $(12,13)$. Several studies reported that lymphocyte levels were lower in prostate cancer (13-15). In this study, we also showed that the lymphocyte counts were significantly lower in the patients with IPCa $(p=0.009)$. Although there was no significant difference $(p=0.086)$, the mean NLR was higher in the patients without IPCa, similar to the other studies $(13,15,16)$. As it was demonstrated in previous studies, a significant difference was observed 
in terms of PLR between the patients with or without IPCa $(13,15,17,18)$ and it was found to be higher in the patients with IPCa $(p=0.010)$. These results suggest that preoperative PLR, NLR, and lymphocyte counts may be an important predictor of IPCa in patients scheduled for open prostatectomy.

Similar to the previous studies which demonstrated an increase in these parameters in case of inflammation in the patients with chronic prostatitis $(12,19)$, when the patients were divided into two groups according to the presence of chronic prostatitis, although there was no significant difference in terms of leukocyte, neutrophil, platelet counts, NLR and PLR between the patients with and without chronic prostatitis, these parameters were higher in the patients with chronic prostatitis. It has been shown that lymphocyte levels decrease and neutrophil counts increase in systemic inflammatory response (19). In this study, it was observed that lymphocyte counts were insignificantly lower in the patients with chronic prostatitis.

This study had some limitations such as being a retrospective study and being conducted in a single center with a small number of patients. On the other hand, we showed that the rate of IPCa in our urology clinic was similar to the literature. In addition, despite these limitations, one of the strengths of our study is that there was a significant relationship between hematological parameters and pathology results in patients who underwent open prostatectomy. Multicenter prospective studies with a larger number of patients to be conducted in the future will eliminate the limitations of this study and more clearly reveal the relationship between hematological parameters and pathology results.

\section{Conclusion}

Although the incidence of the IPCa has decreased in the patients undergoing open prostatectomy due to bladder outlet obstruction and/or LUTS with the increase in the frequency of use of PSA, it continues. Therefore, the rate of IPCa in our study was found to be similar to the literature. Evaluation of preoperative PSA level, as well as hematological parameters such as neutrophil, lymphocyte and platelet counts, NLR, and PLR in the patients who will undergo open prostatectomy will provide both urologists to review their preoperative approaches, and pathologists to examine pathology specimens more carefully in terms of prostate cancer.

\section{Ethics}

Ethics Committee Approval: This study was approved by the Aydın Adnan Menderes University Non-Interventional Clinical Research Ethics Committee (decision no: 11, date: 06.08.2020).

Informed Consent: Informed consent was obtained from patients.

Peer-review: Externally peer-reviewed.

Financial Disclosure: The author declared that this study received no financial support.

\section{References}

1. McVary KT. BPH: epidemiology and comorbidities. Am J Manag Care 2006; 12: 122-8.

2. Gratzke C, Bachmann A, Descazeaud A, Drake MJ, Madersbacher $S$, Mamoulakis C, et al. EAU Guidelines on the Assessment of Non-neurogenic Male Lower Urinary Tract Symptoms including Benign Prostatic Obstruction. Eur Urol 2015; 67: 1099-109.

3. Pariser JJ, Packiam VT, Adamsky MA, Bales GT. Trends in Simple Prostatectomy for Benign Prostatic Hyperplasia. Curr Urol Rep 2016; 17: 57.

4. Otto B, Barbieri C, Lee R, Te AE, Kaplan SA, Robinson B, et al. Incidental prostate cancer in transurethral resection of the prostate specimens in the modern era. Adv Urol 2014; 2014: 627290.

5. Capitanio U, Cheng L, Lopez-Beltran A, Scarpelli M, Freschi $\mathrm{M}$, Montorsi $\mathrm{F}$, et al. The importance of interaction between urologists and pathologists in incidental prostate cancer management. Eur Urol 2011; 60: 75-7.

6. Acharya $A B$, Shetty IP, Jain $S$, Padakannaya I, Acharya $S$, Shettar L, et al. Neutrophil-to-lymphocyte ratio and plateletto-lymphocyte ratio in chronic periodontitis before and after nonsurgical therapy. J Indian Soc Periodontol 2019; 23: 419-23.

7. Meshaal MS, Nagi A, Eldamaty A, Elnaggar W, Gaber M, Rizk H. Neutrophil-to-lymphocyte ratio (NLR) and platelet-tolymphocyte ratio (PLR) as independent predictors of outcome in infective endocarditis (IE). Egypt Heart J 2019; 71: 13.

8. Adhyatma KP, Prapiska FF, Siregar GP, Warli SM. Systemic Inflammatory Response in Predicting Prostate Cancer: The Diagnostic Value of Neutrophil-To-Lymphocyte Ratio. Open Access Maced J Med Sci 2019; 7: 1628-30.

9. Otsubo S, Yokomizo A, Mochida O, Shiota M, Tatsugami K, Inokuchi J, et al. Significance of prostate-specific antigen-related factors in incidental prostate cancer treated by holmium laser enucleation of the prostate. World J Urol 2015; 33: 329-33.

10. Güner E, Şeker KG. Incidental Prostate Cancer and Its Characteristics in Patients Undergoing Open Prostatectomy Due to Benign Prostatic Hyperplasia. Med J Bakirkoy 2019; 15: 87-90. 
11. Schaeffer AJ, Landis JR, Knauss JS, Propert KJ, Alexander RB, Litwin MS, et al. Demographic and clinical characteristics of men with chronic prostatitis: the national institutes of health chronic prostatitis cohort study. J Urol 2002; 168: 593-8.

12. Qin B, Ma N, Tang Q, Wei T, Yang M, Fu H, et al. Neutrophil to lymphocyte ratio (NLR) and platelet to lymphocyte ratio (PLR) were useful markers in assessment of inflammatory response and disease activity in SLE patients. Mod Rheumatol 2016; 26: 372-6.

13. Adhyatma KP, Prapiska FF, Siregar GP, Warli SM. Systemic Inflammatory Response in Predicting Prostate Cancer: The Diagnostic Value of Neutrophil-To-Lymphocyte Ratio. Open Access Maced J Med Sci 2019; 7: 1628-30.

14. Cihan YB, Arslan A, Ergul MA. Subtypes of white blood cells in patients with prostate cancer or benign prostatic hyperplasia and healthy individuals. Asian Pac J Cancer Prev 2013; 14: 477983.
15. Sun Z, Ju Y, Han F, Sun X, Wang F. Clinical implications of pretreatment inflammatory biomarkers as independent prognostic indicators in prostate cancer. J Clin Lab Anal 2018; 32: e22277.

16. Gokce MI, Hamidi N, Suer E, Tangal S, Huseynov A, Ibiş A. Evaluation of neutrophil-to-lymphocyte ratio prior to prostate biopsy to predict biopsy histology: Results of 1836 patients. Can Urol Assoc J 2015; 9: 761-5.

17. Li F, Hu H, Gu S, Chen X, Sun Q. Platelet to lymphocyte ratio plays an important role in prostate cancer's diagnosis and prognosis. Int J Clin Exp Med 2015; 8: 11746-51.

18. Yuksel OH, Urkmez A, Akan S, Yldirim C, Verit A. Predictive Value of the Platelet-To-Lymphocyte Ratio in Diagnosis of Prostate Cancer. Asian Pac J Cancer Prev 2015; 16: 6407-12.

19. Zahorec R. Ratio of neutrophil to lymphocyte counts--rapid and simple parameter of systemic inflammation and stress in critically ill. Bratisl Lek Listy 2001; 102: 5-14. 